\title{
Pencantuman Asas Kewajaran dalam Kontrak Standar (Perjanjian Baku) sebagai Salah Satu Upaya Melindungi Konsumen
}

\author{
Sentosa Sembiring
}

\begin{abstract}
Abstrak
To protect consumers, it is necessary to include reasonbleness principle in a standardized contract should the principle be neglected, the contract be void or, at least, judges can decide that such a contract is unenforceable. Observing the principle, it is hoped that rights and duties of parties in the contract be balance. There is no any reason, therefore, for consumers not to comply with the contract they have concluded.
\end{abstract}

\section{Pendahuluan}

Apabila dicermati perjanjian atau kontrak yang berlaku dalam praktek bisnis dewasa ini, terlihat ada kecenderungan, bahwa kontrak dibuat dalam bentuk Standar. Bentuk kontrak jenis ini oleh para ahli hukum disebut sebagai kontrak standar atau perjanjian baku. Mungkin timbul pertanyaan, apakah kontrak standar ini masih dapat dikualifikasikan sebagai suatu perjanjian yang dibuat atas kesepakatan? Untuk menjawab pertanyaan ini perlu diketahui apa yang dimaksud dengan kontrak standar?' Dalam hal ini, para ahli hukum mencoba merumuskan; perjanjian baku sebagai perjanjian yang hampir seluruh klausulnya sudah dibakukan oleh pemakaiannya dan pihak yang lain pada dasarnya tidak mempunyai peluang untuk merundingkan atau meminta perubahan. ${ }^{2}$ Rumusan senada dikemukakan oleh penulis lain, yakni: Perjanjian yang isinya telah ditetapkan terlebih dahulu secara tertulis berupa formulir-formulir yang digandakan dalam jumlah yang terbatas, untuk dita-

'Istilah apa yang paling tepat digunakan untuk kontrak standar. masih terdapat perbedaan pendapat di antara ahli hukum. Untuk itu dalam literatur dapat ditemui istilah Perjanjian Baku. Pejanjian Standar, Standar Kontrak. Dalam bahasa Inggris digunakan istilah Standart Form Contract. Adhesion Contract, Standardized Contract.

${ }^{2}$ Sutan Remy Syahdeni. 1993. Kebebasan Berkontrak dan Perlindungan yang Seimbang Bagi Para Pihak dalam Perjanjian Kredit di Bank. Jakarta: IBI. Hlm. 65 
warkan kepada konsumen tanpa memperhatikan perbedaan kondisi konsumen. ${ }^{3}$

Dari rumusan yang dikemukakan oleh para ahli hukum di atas, tampak bahwa kontrak standar sudah dipersiapkan terlebih dahulu oleh salah satu pihak. Pada umumnya yang mempersiapkan kontrak standar ini adalah pihak yang mempunyai kedudukan ekonomis lebih tinggi dibandingkan dengan pihak lawannya.

Apabila demikian halnya, apakah pihak yang merasa dirugikan dapat menolak untuk menandatangani perjanjian atau apakah pihak yang merasa dirugikan tersebut, dapat minta kepada pihak pembuat kontrak syarat (kiausul) yang memberatkan tersebut dihilangkan/ dikesampingkan? Dalam hal ini bagi pihak konsumen hanya ada dua pilihan yakni tunduk kepada klausul yang dicantumkan pembuat perjanjian baku atau meninggalkan dalam arti tidak menandatangani (take it or leave it). Pilihan apa pun yang dilakukan konsumen, mempunyai konsekuensi tersendiri yakni bila menandatangani harus tunduk kepada syaratsyarat yang ditentukan. Bila tidak, maka harapan untuk mendapat sesuatu, hilang. Karena itu, bila posisi para pihak dalam perjanjian mempunyai posisi yang sama, maka bila klausul dianggap memberatkan kontrak tidak ditandatangani (leave it). Tetapi bagi pihak yang tidak mempunyai kedudukan yang sama, tidak ada pilihan lain harus menandatangani (take it), dengan suatu konsekuensi yang harus ditanggung.

Melihat fenomena kontrak standar dalam praktik bisnis, timbul pertanyaan dari kalangan juris, apakah hal ini sudah memenuhi asas- asas hukum perjanjian? Untuk menjawab masalah ini, perlu dicermati apa yang dimaksud dengan perjanjian. Dalam Pasal $1313 \mathrm{KUH}$ Perdata disebutkan: "Perjanjian adalah suatu perbuatan dengan mana satu orang atau lebih mengikatkan dirinya terhadap satu orang atau lebih". Selanjutnya dalam Pasal 1320 KUHPerdata disebutkan: "Untuk syahnya suatu perjanjian diperukan 4 syarat yaitu: (1) Sepakat mereka yang mengikatkan dirinya; (2) Kecakapan untuk membuat suatu perikatan; (3) $\mathrm{Hal}$ tertentu; (4) Suatu sebab yang halal".

Dengan mengacu kepada ketentuanketentuan di atas, apabila perjanjian dibuat memenuhi syarat yang ditentukan dalam UU, maka perjanjian tersebut mengikat kedua belah pihak dalam arti dengan adanya perjanjian antara dua pihak atau lebih maka, muncul hak dan kewajiban. Hal ini dengan tegas dicantumkan dalam Pasal 1338 KUHPerdata sebagai berikut:

(1) Semua perjanjian yang dibuat secara sah berlaku sebagai undang-undang bagi mereka yang membuatnya;

(2) Perjanjian tidak dapat ditarik kembali, selain dengan sepakat kedua belah pihak atau karena alasan-alasan yang oleh undang-undang dinyatakan cukup untuk itu;

(3) Perjanjian harus dilaksanakan dengan iktikad baik.

Ketentuan Pasal 1338 ayat (1) KUHPerdata, oleh para ahli hukum dianggap sebagai dasar hukum untuk melakukan kebebasan berkontrak (the freedom of contract), artinya

3Johannes Gunawan. "Penggunaan Perjanjian Standar dan Implikasinya padaAsas Kebebasan Berkontrak". Dalam Projustitia No. 3 Tahun V Edisi Oktober 1987. HIm. 4. 
para pihak yang mengadakan perjanjian, dapat membuat apa yang diinginkan oleh mereka. Lalu timbul pertanyaan, apakah kebebasan berkontrak tidak ada batasannya, dalam arti setiap pihak dapat membuat kontrak apa saja, asal disepakati oleh kedua belah pihak? Dalam hal ini periu dicermati secara seksama apa yang dicantumkan dalam Pasal 1338 ayat (3) KUHPerdata, perjanjian harus dilaksanakan dengan iktikad baik. Dari ketentuan ini, ada satu hal yang harus diperhatikan oleh pihak yang terkait dalam perjanjian tersebut yaitu harus mempunyai iktikad baik.

Pentingnya iktikad baik ini, karena adakalanya dalam pelaksanaan kontrak yang sudah ditandatangani oleh para pihak, tidak berjalan sesuai dengan harapan masingmasing. Mengapa demikian? Karena ada perbedaan penafsiran terhadap isi kontrak itu sendiri. Apabila demikian hainya, apakah pihak yang tidak mau melaksanakan perjanjian dapat langsung dikualifikasikan sebagai ingkar janji (wanprestasi)? Agaknya pandangan yang mengatakan, bila kontrak yang sudah ditanda-. tangani tidak dipenuhi, maka pihak yang tidak mematuhi kontrak dapat digugat dengan ingkar janji. Sebagaimana dijabarkan dalam Pasal 1239 KUHPerdata; "Trap-tiap perikatan berbuat sesuatu atau tidak berbuat sesuatu, apabila si berhutang tidak memenuhi kewajibannya, mendapatkan penyelesaiannya dalam kewajibannya memberikan penggantian biaya, rugi dan bunga". Dalam ketentuan ini, belum ada syarat apa yang harus dipenuhi untuk kualifjkasi wanprestasi.

Dalam hal ini menarik untuk dicermati Hukum Kontrak Inggris, ${ }^{4}$ yang dengan tegas mengemukakan bahwa pihak yang melanggar kontrak wajib membayar ganti rugi kepada pihak yang dirugikan, asal kontrak yang ditandatangani memenuhi syarat yakni: a) jelas maksud mengadakan perjanjian; b) persetujuan yang tetap; c) prestasi; d) bentuknya; e) syarat-syarat tertentu; dan f) kausa yang halal.

Bagaimana halnya hukum kontrak di Indonesia? Dalam hal ini ada beberapa pasal yang dapat dijadikan bahan acuan yakni Pasal 1239 KUHPerdata yang mengemukakan bahwa tiap-tiap perikatan untuk berbuat sesuatu, atau untuk tidak berbuat sesuatu, apabila yang berutang tidak memenuhi kewajibannya, mendapatkan penyelesaiannya dalam kewajiban memberikan penggantian biaya, rugi dan bunga. Selanjutnya dalam Pasal 1243 KUHPerdata disebutkan bahwa penggantian biaya, rugi dan bunga karena tidak dipenuhinya suatu perikatan, barulah mulai diwajibkan, apabila yang berutang, setelah dinyatakan lalai memenuhi perikatannya, tetap melalaikannya, atau jika sesuatu yang harus diberikan atau dibuatnya, hanya dapat diberikan atau dibuat dalam tenggang waktu yang telah dilampaukannya.

Dalam Pasal 1343 KUHPerdata disebutkan, jika kata-kata suatu persetujuan dapat diberikan berbagai macam penafsiran, harus dipilihnya menyelidiki maksud kedua belah pihak yang membuat persetujuan itu, daripada memegang teguh arti kata-kata menurut huruf. Selanjutnya dalam Pasal 1346 KUHPerdata disebutkan bahwa apa yang meragu-ragukản harus ditafsirkan menurut apa yang menjadi kebiasaan dalam negeri atau di tempat di mana persetujuan telah dibuat.

^Abdul Kadir Muhammad. 1980. Hukum Perjanjian. Bandung:Alumni. Hlm. 95. 
Dengan mengacu kepada keter:uanketentuan yang tercantum dalam KUHPE.data, secara normatif, bila ada pihak yang merasa dirugikan dapat menuntut pihak lainnya. Sesuai dengan hakekat kebebasan berkontrak, tampaknya perlu dicantumkan klausụl yang dapat melindungi konsumen.

\section{Kontrak Standar dalam Praktik Bisnis}

Disadari atau tidak, perjanjian atau kontrak yang berlaku dalam praktik bisnis dewasa ini, pada umumnya sudah menggunakan kontrak standar. Apabila demikian halnya, timbul pertanyaan apakah dengan adanya standar kontrak tersebut, masih berlaku asas kebebasan berkontrak dalam hukum perjanjian?

Untuk menjawab pertanyaan di atas kiranya perlu ditelaah secara seksama pengaturan hukum perjanjian di Indonesia, dalam hal ini Buku III Kitab Undang-Undang Hukum Perdata (KUHPerdata). Para ahli hukum, pada umumnya berpendapat, bahwa Buku III KUHPerdata yang mengatur hukum perjanjian menganut Sistem Terbuka, ${ }^{5}$ artinya Hukum Perjanjian memberikan kebebasan yang seluas-luasnya kepada masyarakat untuk mengadakan perjanjian yang berisi dan bermuatan apa saja asal tidak melanggar ketertiban umum dan kesusilaan. Pasal-pasal dari hukum pejianjian merupakan hukum pelengkap (optional law). Oleh karena itu, pasal-pasal dalam ketentuan Hukum Perjanjian boleh diabaikan, apabila dikehendaki oleh kedua. belah pihak yang membuat perjanjian. Mereka boleh membuat ketentuan sendiri yang mereka kehendaki.

Ada satu hal yang kiranya harus diperhatikan, bahwa sekalipun hukum perjanjian menganut sistem terbuka, namun tidak berarti para pihak bebas sebebas-bebasnya dalam membuat perjanjian, tetapi harus mengindahkan ketertiban umum dan kesusilaan walaupun harus disadari, agak sulit untuk menentukan kriteria ketertiban umum dan kesusilaan. Namun sebagai pedoman, kiranya dapat dipakai ukuran yakni kewajaran (reasonableness). Ini berarti harus memperhatikan normanorma yang hidup dalam masyarakat.

Hukum perjanjian menganut sistem terbuka dapat disimpulkan dari Pasal 1338 ayat (1) KUHPerdata yang mengemukakan bahwa: "Semua perjanjian yang dibuat secara sah berlaku sebagai Undang-undang bagi mereka yang membuatnya".

Dengan mengacu kepada ketentuan di atas, masyarakat dapat membuat perjanjian apa saja yang diinginkan sepanjang memenuhi syarat-syarat sahnya suatu perjanjian, sebagaimana yang diatur dalam Pasal 1320 KUHPerdata. Pasal ini oleh para ahli hukum ${ }^{6}$ disebut sebagaimana ketentuan yang mengatur masalah asas Konsensualisme dalam Hukum Perjanjian artinya perjanjian adalah sah apabila ada kata sepakat mengenai halhal yang pokok.

Lalu apa konsekuensi yang muncul dengan dicapainya kata sepakat oleh pihak yang membuat kontrak? Dengan adanya kata

${ }^{5}$ R. Subekti. 1976. Hukum Perjanjian. Jakarta:Intermasa. HIm. 13. dan lihat Suryodiningrat. 1978. AzasAzas Hukum Perikatan. Bandung: Tarsito. HIm. 23.

${ }^{6}$ bid. 
sepakat, maka pada saat itulah muncul hak dan kewajiban para pihak. Ini berarti bila para pihak tidak mematuhi kewajibannya dapat digugat oleh pihak lainnya. Yang menjadi pertanyaan adalah sejak kapan kata sepakat dianggap sudah ada. Apakah pada saat ditandatanganinya kontrak pada saat penawaran disetujui ojeh kedua belah pihak?

Dalam hal ini timbul berbagai pendapat, antara lain yang mengemukakan sebagai berikut: Maka dari itu, kalau membicarakan tentang perjanjian baku dan menempatkan secara dogmatis dalam asas-asas hukum perjanjian, sebagaimana yang dikemukakan oleh para ahli hukum seabad yang lampau, tentu akan terjadi tubrukan dengan asas-asas dari hukum perjanjian yakni kebebasan berkontrak, terutama dengan persesuaian kehendak yang merupakan dasar dari perjanjian, kalau kebebasan dari para pihak dipegang teguh, maka kadang-kadang akan dapat mengurangi kebebasan dari salah satu pihak.

Andaikata orang tidak membaca syaratsyarat perjanjian atau membaca tetapi tidak mengerti maksudnya dan menandatangani perjanjian itu, maka persesuaian kehendak itu telah berlaku. Untuk itu perlu memperluas sistemnya dengan menggunakan jasa baik dari asas kepercayaan (vertrouwens beginse). Ajaran ini telah mengganti ajaran kehendak (wilsleer).

Pikiran persesuaian kehendak yang merupakan ajaran umum, dalam perjalanan puluhan tahun terakhir ini telah ditinggalkan.
Kehendak tidak lagi merupakan norma-norma esensial dari perbuatan hukum, ia ada di bawah norma-norma pergaulan masyarakat yaitu sesuatu hal yang penting untuk menafsirkan perbuatan hukum. Di sini yang penting adalah kehendak dari pembuat untuk menimbulkan akibat hukum, apabila kehendak itu tidak ada atau cacat, maka perbuatan hukum itu batal atau dapat dibatalkan.?

Kapan suatu perjanjian batal atau dapat dibatalkan? Dalam hal ini para ahli hukum berpendapat apabila syarat pertama dan kedua yakni kata sepakat dan kecakapan dalam Pasal 1320 KUHPerdata tidak dipenuhi, maka perjanjian batal demi hukum (null and void) artinya dari semula dianggap tidak ada perjanjian. Jadi tidak mengikat para pihak. ${ }^{8}$

Bagaimana halnya dengan Kontrak Standar, apakah dapat dinyatakan batal demi hukum atau dapat dibatalkan oleh salah satu pihak yang merasa dirugikan dengan syaratsyarat yang dicantumkan dalam Kontrak Standar? Untuk itu perlu diperhatikan munculnya Kontrak Standar itu sendiri.

Munculnya kontrak standar dalam lalu lintas hukum, dilandasi oleh kebutuhan akan pelayanan yang efektif dan efisien terhadap kegiatan transaksional. Oleh karena itu, karakter utama dari kontrak standar adalah pelayanan yang cepat (efisien) terhadap kegiatan transaksional yang berfrekuensi tinggi, namun tetap dapat memberikan kekuatan serta kepastian hukum (efektif). Agar kontrak standar dapat memberikan pelayanan yang cepat,

'Purwahid Patrik. 1998. "Perjanjian Baku dan Penyalahgunaan Keadaan". Dalam Hukum Kontrak di Indonesia. Jakarta: Elips. Him. 145.

${ }^{8}$ R. Subekti. Op. Cit. HIm. 19. 
maka isi (kondisi/syarat) perjanjian kontrak standar harus ditetapkan lebiti dahulu secara tertulis dalam bentuk formuli ini kemudian ditawarkan kepada konsumen tanpa memperhatikan kondisi mereka satu sama lain.9

Jadi di sini, semakin tampak bahwa keberadaan kontrak standar dalam lalu lintas hukum, khususnya di kalangan praktik bisnis, dianggap lebih efisien dan mempercepat proses transaksi bisnis. Bagi pihak-pihak yang akan melakukan hubungan hukum, dalam hal ini konsumen, ada kalanya tidak sempat mempelajari syarat-syarat perjanjian yang dicantumkan oleh pihak produsen dalam kontrak standar. Syarat (klausul) yang dimaksud adalah adanya pembatasan atau bahkan pembebasan tanggung jawab seseorang dalam melaksanakan perjanjian. Klausul pembebasan ini oleh para ahli hukum disebut dengan klausul eksonerasi (exoneratie clausule)..$^{10}$ Maksud pencantuman klausul ini adalah membatasi tanggung jawab, bila ada gugatan dari pihak lain, karena tidak melaksanakan perjanjian atau tidak semestinya melakukan perjanjian.

Dengan adanya klausal tersebut, jelas posisi pinak yang membuat kontrak standar cukup kuat, mengapa? Karena dari awal, ia sudah menyatakan tidak bertanggung jawab dalam hal ia lalai untuk melaksanakan perjanjian. Untuk memahami lebih seksama, klausul eksonerasi, berikut dikutip klausul yang tercantum dalam formulir pembayaran melalui Bank International Indonesia (BII) sebagai berikut:
"Dalam menerima setoran-setoran, BII hanyalah merupakan agen saudara atas setoran-setoran yang masih harus ditagih dan tidak bertanggung jawab atas diperolehnya tagihan tersebut. Apabila pembayaran atas jumlah setoran tersebut akan dibebankan kembali ke dalam rekening saudara termasuk jumlah cek pada Bank yang tidak dapat dibayar disebabkan tidak cukupnya dana, pemalsuan, perintah penghentian pembayaran atau alasan lain apa saja dan tanpa menghiraukan apakah setoran itu dikembalikan kepada saudara atau tidak. Apa-apa yang disetorkan diterima Bll dengan pengertian bahwa saudara bertanggung jawab penuh atas keaslian, sahnya dan benamya semua tandatangan dan edosemen yang tertera pada apa-apa yang disetor tadi".

Apabila dicermati klausal yang tercantum dalam formulir di atas, posisi atau kedudukan pengguna jasa perbankan masih dapat dikatakan ada keseimbangan dengan posisi bankir. Disebut demikian, karena bank hanyalah sebagai kuasa (agen) untuk menagih atas perintah nasabah. Tentunya, risiko atas tidak berhasilnya untuk menagih piutang tersebut wajar dibebankan ke pemberi kuasa (pemberi amanat) karena ketidaklengkapan persyaratan yang harus dipenuhi, misalnya keaslian tanda tangan dalam endosemen.

Contoh lain klausul eksonerasi misalnya klaưsul yang mencantumkan seperti ini: "Kesalahan dalam pengisian formulir ini adalah tanggung jawab nasabah". Adalah wajar, bila

'Johannes Gunawan. Op. Cit. Him. 45.

${ }^{10}$ Padanan kata yang paling tepat untuk exoneratie clausule, belum ada kesatuan pendapat di antara para ahli hukum. Misalnya Sutan Remy Syahdeni, menggunakan istilah klausul eksemsi. Lihat Sutan Remy Syahdeni. Op. Cit. HIm. 72. 
kesalahan dibebankan kepada pihak yang membuat kesalahan. Akan tetapi, tidak ditemui risiko apa yang harus ditanggung oleh bank dalam hal kesalahan ada di pihak bank. Di sinilah terlihat ketidakseimbangan dalam kontrak standar yang banyak dijumpai dalam praktik bisnis yang sudah merambah keseluruh sektor, tidak hanya di bisnis perbankan.

Perhatikan misalnya klausul dalam Perjanjian Kredit Bank. Acapkali ditemui klausul sebagai berikut: "Penerimaan kredit wajib sepenuhnya kepada segala petunjuk dan peraturan serta ketentuan yang telah maupun yang masih akan ditetapkan kemudian oleh bank, sehubungan dengan pemberian kredit ini". Di sini, tampak posisí debitur cukup lemah, karena dia harus tunduk kepada seluruh ketentuan Bank yang ditetapkan secara sepihak. Contoh klasik dalam hal ini adalah bunga kredit, yang bisa setiap waktu dapat berupa, debitur harus patuh.

Apakah pencantuman klausul yang demikian dianggap sah, karena disepakati oleh kedua belah pihak. Lagi pula, bukankah dalam hukum kontrak dianut asas kebebasan berkontrak yang berarti para pihak dapat mencantumkan syarat-syarat apa saja yang diinginkan?

Dalam hal ini, memang belum ada suatu undang-undang khusus yang mengatur masalah kontrak standar, dalam arti hal-hal yang tidak perlu dicantumkan dalam kontrak standar. Khusus dalam dunia perbankan sebenarnya, sudah ada rambur-rambu yang dijabarkan UU No. 7 Tahun 1992 jo UU No: 10 Tahun 1998. Dalam Pasal 29 ayat (5) disebut, "Untuk kepentingan nasabah, bank menyediakan informasi mengenai kemungkinan timbulnya risiko kerugian bagi transaksi nasabah yang

\footnotetext{
"Abdul Kadir Muhammad. Op. Cit. 154.
}

dilakukan melalui bank". Selanjutnya dalam penjelasan pasal ini dikemukakan: "Informasi yang disediakan untuk nasabah tersebut adalah informasi mengenai tingkat risiko dari kegiatan yang menjadi sasaran penggunaan atau penempatan dana. Apabila informasi telah disediakan, maka bank dianggap telah melaksanakan ketentuan ini. Informasi tersebut perfu diberikan oleh bank, dalam hal bank bertindak sebagai perantara dalam melakukan penempatan dana dari nasabah atau membeli/menjual surat berharga untuk kepentingan dan atas perintah nasabahnya".

Bagaimana bentuk informasi yang dimaksud, apakah dicantumkan dalam kontrak standar atau secara lisan belum jelas. Lain halnya di Inggris, di sana sudah ada undangundang tentang syarat-syarat perjanjian yang tidak adil (The Unfair Contract Terms Act; 1977). Dalam undang-undang ini disebutkan, tidak seorang pun dapat bertindak dalam suatu perdagangan dapat mengesampingkan tanggung jawab dalam perjanjian atau kesalahan perdata, baik dengan syarat-syarat perjanjian maupun dengan suatu pemberitahuan yang diberikan atau dipanjangkan bagi kematian atau luka badan yang timbul sebagai akibat kelalaian. la hanya dapat mengesampingkan tanggung jawab bagi kerugian lainnya karena kelalaiannya, tetapi hanya jika ia dapat membuktikan bahwa pengesampingan itu layak. Selain ketentuan di atas, di Inggris juga dapat ditemui Undang-undang Perdagangan Wajar (The Fair Trading Act, 1973). Menurut Undangundang ini. Menteri Perdagangan dan Perindustrian, mempunyai kekuasaan untuk membuat peraturan-peraturan yang melarang praktik dagang konsumen tertentu yang tidak diinginkan." 
Indonesia belum memiliki undang-undang yang mengatur secara khusus seperti halnya di inggris tersebut. Namun tidak berarti, bahwa para pihak bebas dalam menentukan syarat-syarat yang diinginkan dalam Kontrak Standar, sebagaimana dapat ditemui, dalam perdagangan internasional acapkali ditemui adanya pilihan hukum. Dalam doktrin, maupun dalam yurisprudensi, kebebasan para pihak untuk memilih hukum mana yang berlaku itu tidak berarti bahwa pilihan boleh dilakukan secara sewenang-wenang, karena terdapat berbagai pembatasan, yaitu: a) sepanjang tidak melanggar ketertiban umum; b) tidak boleh menjadi penyelundupan hukum; dan $\mathrm{c}$ ) hanya boleh dilangsungkan berkenaan dengan bidang hukum perjanjian. ${ }^{12}$

\section{Asas Kewajaran dalam Kontrak Standar}

Apabila dicermati lahirnya asas Kebebasan Berkontrak, tidak dapat dilepaskan dari paham individualisme yang mengutamakan adanya persamaan hak di antara individuindividu. Hal ini pun tampak dalam pengaturan hak-hak individu, sebagaimana yang dijabarkan dalam Kitab Undang-Undang Hukum Perdata (KUHPerdt) bahwa seorang bayi dalam kandungan pun, bila kepentingannya menghendaki dianggap sudah lahir (lihat Pasal 2 KUHPerdt). Jadi di sini terlihat, bahwa kedudukan individu dalam lalu lintas pergaulan hukum dianggap sah (sederajat) satu sama lain.
Oleh karena itu, para pihak saling mengikat diri sebagaimana yang dijabarkan dalam Pasal 1233 KUHPerdt, tiap-tiap perikatan dilahirkan baik karena persetujuan maupun karena undang-undang. Selanjutnya dalam Pasal 13.13 KUHPerdt disebutkan, suatu persetujuan adalah suatu perbuatan dengan mana satu orang atau lebih mengikatkan dirinya terhadap satu orang lain atau lebih. Sedangkan syarat-syarat yang harus dipenuhi untuk sahnya suatu perjanjian diatur dalam Pasal 1320 KUHPerdt, yakni: (1) sepakat bagi mereka yang mengikat dirinya; (2) kecakapan untuk membuat perikatan; (3) adanya suatu hal tertentu; (4) adanya suatu sebab yang halal.

Yang menjadi pertanyaan adalah apakah perjanjian yang sudah disepakati oleh para pihak, cukup dibuat secara lisan (oral contract) atau dibuat secara tertulis (written contract)? Dalam kehidupan masyarakat yang masih sederhana, tampaknya perjanjian tersebut cukup dibuat secara lisan. Dengan kata lain, apả yang sudah disepakati kedua belah pihak mengikat bagi mereka dan itulah Undangundang. Tampaknya asas seperti ini pun dapat ditemui dalam asas Hukum Romawi kuno, yang dikenal dengan istilah pacta sunt servanda artinya perjanjian yang sudah disepakati harus sungguh-sungguh ditepati. ${ }^{13}$

Bagaimana halnya dalam masyarakat modern, atau tepatnya di era globalisasi ini, apakah perjanjian/kontrak cukup dibuat secara lisan? Dalam dekade terakhir ini, tampak

${ }^{12} \mathrm{BM}$. Kuntjoro Jakti. "Pengaturan Perdagangan International Pengalaman Indonesia dalam Praktik". Dalam Jual Beli Barang secara International. Jakarta: Elips. HIm. 99.

${ }^{13}$ Lihat Kamus Hukum Foekerna Andera. Terjemahan Saleh Adiwinata, dkk. 1983. Bandung: Bina Cipta. HIm. 384. 
bahwa masyarakat berpacu dengan waktù. Untuk itu diperlukan sistem kerja yang cepat dan efisien, tidak terkecuali dalam dunia bisnis. Oleh karena itu, di kalangan dunia bisnis butuh kepastian hukum, bila ada perselisihan di kemudian hari. Upaya yang dilakukan dalam hal ini, antara lain dengan Kontrak Standar atau pembakuan șurat-surat kontrak. Bahkan di tingkat Perdagangan Internasional telah diatur dalam International Sales of Goods, yang dikenal Konvensi Vienna 1980. Konvensi ini bertujuan untuk meningkatkan International Trade atas dasar kesamaan derajat dan kemampuan bersama dan kemanfaatan bersama yang merupakan unsur yang penting dalam peningkatan hubungan persahabatan antarnegara.

Hal ini didasarkan atas pendapat bahwa pemberlakukan ketentuan-ketentuan seragam yang mengatur kontrak-kontrak international sales of goods dengan memperhatikan sistem-sistem sosial, ekonomi, dan hukum yang berbeda, akan memberikan sumbangan terhadap penghapusan hambatan-hambatan hukum dalam international trade dan mendorong peningkatan intemational trade. ${ }^{14}$

Apabila yang mengadakan hubungan hukum antarsesama pengusaha, Kontrak Standar sebenarnya tidak ada masalah, karena mereka berpegang pada prinsip ekonomi yang sama dengan menerapkan sistem bersaing secara sehat dalam melayani konsumen. Tetapi dalam hubungan hukum antara pengusaha dan konsumen (common consum- ers) justru muncul permasalahan utama yaitu kemampuan konsumen memenuhi syaratsyarat yang telah diterapkan secara baku dan sepihak oleh pengusaha. Dalam hal ini konsumen harus menerima segala akibat yang timbul dari perjanjian tersebut, walaupun akibat itu merugikan konsumen tanpa kesalahannya. Di sini konsumen dihadapkan pada satu pilihan yaitu menerima dengan besar hati: ${ }^{15}$

Salah satu syarat yang harus dipenuhi dalam menerapkan asas kebebasan berkontrak adalah adanya itikad baik dari para pihak yang membuat kontrak. Itikad baik di waktu membuat suatu perjanjian berarti kejujuran. Orang yang beritikad baik menaruh kepercayaan sepenuhnya kepada pihak lawan, yang dianggapnya jujur dan tidak menyembunyikan suatu yang buruk yang kemudian hari dapat menimbulkan kesulitan-kesulitan. Itikad baik dalam tahap pelaksanaan perjanjian adalah kepatutan yaitu suatu penilaian baik terhadap tindak tanduk suatu pihak dalam hal melaksanakan apa yang dijanjikan. ${ }^{16}$

Berangkat dari pemikiran ini, tentunya pihak pembuat kontrak standar tidak akan gegabah dalam membuat syarat-syarat yang harus diikut oleh pihak lawan. Walaupun harus disadari pula bahwa pihak pembuat kontrak, dalam hal ini pihak konsumen harus menyadari pula, bahwa dengan mengikatkan diri, melahirkan kewajiban-kewajiban hukum.

$\mathrm{Hal}$ ini perlu ditekankan mengapa? Karena perjanjian tidak dapat dibatalkan karena

${ }^{14}$ Lihat B.M. Kuntjoro Jakti. Op Cit. HIm. 96.

${ }^{15}$ Lihat Abdul Kadir Muhammad. 1992. Perjanjian Baku dalam Praktek Perusahaan Perdagangan. Bandung: Citra Aditya Bakti. Hlm. 4.

${ }^{16}$ R. Subekti. 1976. Aspek-Aspek Hukum Perikatan Nasional. Bandung: Alumni. HIm. 26. 
ada kekhilafan. Dengan menandatangani perjanjian dianggap mengetahui isi dan syaratsyarat perjanjian. Lain halnya kalau terjadi penyalahgunaan keadaan yaitu apabila seorang mengetahui, atau seharusnya mengerti bahwa pihak lain karena keadaan-keadaan tertentu (misalnya: dalam keadaan kepicikan, keadaan jiwa yang abnormal atau tidak berpengalaman) tergerak untuk melakukan perbuatan-perbuatan hukum. Penyalahgunaan keadaan (under influence) merupakan syarat dalam mengajukan tuntutan yang merugikan pihak lain.

Dalam lalu lintas hukum hal ini dapat terjadi, dalam penandatanganan kontrak standar di mana pihak konsumen tidak bebas dalam menentukan pilihannya. Dalam hukum positif telah mengenal pula, bahwa kalau salah satu pihak merugikan pihak lain sebagai akibat penyalahgunaan keadaan, Hoge Raad dalam hal ini memutuskan, bahwa perjanjian ini adalah bertentangan dengan kesusilaan dan Pasal 1377 KUHPerdt ${ }^{17}$ yang mengemukakan bahwa Suatu sebab adalah terlarang, apabila dilarang oleh Undang-undang, atau apabila berlawanan dengan kesusilaan atau ketertiban umum.

Dengan demikian sekalipun para pihak diberi kebebasan untuk membuat perjanjian, namun tidak berarti para pihak bebas membuat syarat-syarat yang dapat menguntungkan salah satu pihak dan merugikan pihak lainnya. Demikian juga halnya dalam kontrak standar, pencantuman klausula eksonerasi dalam kon- trak standar untuk mencegah pihak konsumen dirugikan pengusaha. ${ }^{18}$

Di Indonesia, walaupun secara teoritis dan normatif dilarang mencantumkan klausula eksonerasi yang merugikan pihak konsumen, namun belum ditemui ada Putusan $\mathrm{Pe}$ ngadilan yang membatalkan pencantuman klausul yang memberatkan konsumen tersebut. Lain halnya di Amerika Serikat maupun di Inggris, di sana dengan tegas disebutkan, bila menyimpang dari aturan dasar yang telah ditentukan, maka hakim akan memutuskan bahwa klausul itu tidak dapat diterima sebagai bagian dari perjanjian, dan karena itu para pihak tidak terikat oleh klausul tersebut. ${ }^{19}$

Bagaimana halnya peran pemerintah sendiri? Sebagai payung dalam upaya perlindungan hukum terhadap konsumen, muncul UU No. 8 Tahun 1999 tentang Perlindungan Konsumen, namun secara parsial, upaya untuk itu dalam peraturan perundang-undangan telah mulai muncul, antara lain dalam bidang asuransi. Dalam PP No. 73 Tahun 1992 tentang Penyelenggaraan Usaha Perasuransian disebutkan, dalam setiap pemasaran program asuransi, harus diungkapkan informasi yang relevan, tidak ada yang bertentangan dengan persyaratan yang dicantumkan dalam polis dan tidak menyesatkan (lihat Pasal 17). Selanjutnya dikemukakan, polis atau bentuk perjanjian asuransi dengan nama apa pun, berikut lampiran yang merupakan satu kesatuan dengannya, tidak boleh mengandung kata, kata-kata, atau kalimat

${ }^{17}$ Patrik Purwahid. Op. Cit. Hlm. 153.

${ }^{18} \mathrm{Abdul}$ Kadir Muhammad. Op. Cit. HIm. 20.

${ }^{19}$ St. Remy Sjahdeni. Op. Cit. Him. 78. 
yang dapat menimbulkan penafsiran yang berbeda mengenai resiko yang ditutup asuransinya, kewajiban penanggung dan kewajiban tertanggung, atau mempersulit tertanggung mengurus haknya (lihat Pasal 19 ayat 1 ). Tampaknya Pemerintah "mulai" melakukan pengawasan, terhadap kontrak standar yang dapat merugikan masyarakat seperti halnya dalam bisnis asuransi. Untuk itu, sebelum produk asuransi dipasarkan, harus dilaporkan terlebih dahulu kepada Menteri Keuangan (lihat Pasal 18 ayat (1)).

Asuransi adalah suatu perjanjian. Hal ini dengan tegas dikemukakan dalam Pasal 246 KUHD, "Asuransi atau pertanggungan adalah suatu perjanjian, dengan mana seorang penanggung mengikatkan diri kepada seorang tertanggung, dengan menerima suatu premi, untuk memberikan penggantian kepadanya karena suatu kerugian, kerusakan atau kehilangan keuntungan yang diharapkan, yang mungkin akan dideritanya karena suatu peristiwa yang tertentu".

Hal ini berarti dengan disepakatinya syaratsyarat perjanjian, yang pada umumnya sudah dicantumkan dalam ketentuan polis asuransi, mengikat baik bagi penanggung maupun tertanggung. Oleh karena itu, adalah wajar dan pantas, bila produk yang akan ditawarkan oleh perusahaan asuransi (penanggung), beserta dengan syarat-syarat dalam kontraknya, perlu diketahui oleh pemerintah sebagai pejabat yang memiliki otoritas untuk mengawasi apakah suatu kontrak bertentangan dengan UU atau ketertiban umum. Dengan adanya pengawasan ini, diharapkan klausul-klausul yang dicantumkan tidak merugikan salah satu pihak. Untuk itu prinsip kewajaran dalam membuat kontrak perlu ditaati.
Jadi di sini terlihat, bahwa sekalipun diberi kebebasan untuk membuat kontrak kepada para pihak, namun tidak boleh bertentangan dengan peraturan perudang-undangan dan nilai-nilai kepatutan yang ada dalam masyarakat. Untuk itu perlu kiranya diperhatikan rambu-rambu yang dijabarkan dalam Pasal 1337 KUHPerdt, yaitu suatu sebab adalah terlarang, apabila dilarang oleh Undang-undang atau apabila berlawanan dengan kesusilaan atau ketertiban umum:

Bagaimana mengimplementasikan ketentuan dalam praktik bisnis, tampaknya perlu penjabaran lebih lanjut, mengapa? Karena sebab (causa) apa yang dilarang oleh UU, atau bertentang dengan ketertiban umum dan kesusilaan, perlu ada suatu kriteria tertentu, agar tidak terdapat interpretasi yang berbeda yang dapat membawa ketidaktertiban dalam berusaha (berniaga).

\section{Simpulan}

Penggunaan kontrak standar dalam praktik bisnis pada masa mendatang, tampaknya menjadi suatu hal yang dianggap dapat mempercepat lalu lintas bisnis. Kecenderungan ini dalam tahun-tahun terakhir ini mulai terihat, sebagaimana dapat ditemui di bisnis perbankan. Pengguna jasa perbankan cukup mengisi formulir yang telah disediakan oleh Bank, bila ingin menggunakan jasa perbankan tersebut.

Sepintas lalu, kontrak standar tersebut tidaklah menimbulkan masalah yuridis. Akan tetapi, bila dicermati secara seksama, kedudukan hukum pengguna jasa (konsumen) sangat lemah bila dibandingkan dengan kedudukan produsen (pembuat kontrak standar), karena pada umumnya pihak produsen melindungi dirinya dengan membuat pembatasan- 
pembatasan tanggung jawab dengan mencantumkan klausul yang cukup memberatkan konsumen.

Dalam rangka untuk memberikan perlindungan kepada konsumen, kiranya perlu mencantumkan asas kewajaran (reasonableness) dalam kontrak standar. Bila asas ini tidak diperhatikan, maka kontrak tersebut batal demi hukum atau paling tidak Hakim dapat memutuskan, bahwa klausul yang memberatkan konsumen dapat dinyatakan tidak berlaku. Dengan adanya pencantuman asas tersebut, diharapkan hak dan kewajiban para pihak dalam Kontrak Standar, ada keseimbangan. Bila hal ini dapat dilakukan, maka tidak ada alasan lagi bagi konsumen untuk tidak mematuhi kontrak yang sudah ditandatangani.

\section{Daftar Pustaka}

Muhammad, Abdul Kadir. 1980. Hukum

Perjanjian. Bandung: Alumni.
1992. Perjanjian Baku dalam Praktik Perusahaan Perdagangan. Bandung: CitraAditya Bakti.

Hukum Kontrak di Indonesia. 1998. Jakarta: Elips.

Subekti, R. 1976. Hukum Perjanjian. Jakarta: Intermasa.

_-1976. Aspek-Aspek Hukum Perikatan Nasional. Bandung: Alumni.

Suryodiningrat. 1978. Azas-azas Hukum Perikatan. Bandung: Tarsito.

Syahdeni, Sutan Remy. 1993. Kebebasan Berkontrak dan Perlindungan Yang Seimbang bagi para Pihak dalam Perjanjian Kredit di Bank. Jakarta: IBI.

Jual Beli Barang secara International. Jakarta: Elips.

Kamus Hukum Foekerna Andrea. Terjemahan Saleh Adiwinata, dkk. 1983. Bandung: Bina Cipta.

Projustitia No. 3 Tahun V Edisi Oktober 1987. 